\title{
ANGKA KEJADIAN MEROKOK PADA PASIEN TB PARU YANG BEROBAT DI POLIKLINIK DOTS PADA BULAN NOVEMBER 2014
}

\author{
${ }^{1}$ Widyanita K. Silo \\ ${ }^{2}$ M. C. P. Wongkar \\ ${ }^{2}$ Yuanita A. Langi
}

\author{
${ }^{1}$ Kandidat Skripsi Fakultas Kedokteran Universitas Sam Ratulangi Manado \\ ${ }^{2}$ Bagian Ilmu Penyakit Dalam Fakultas Kedokteran Universitas Sam Ratulangi Manado \\ Email: swidyanita@yahoo.com
}

\begin{abstract}
Lung Tuberculosis is an infectious disease that remains as a public health problem. Several studies suggest a significant relationship between smoking and lung tuberculosis. This study aimed to determine the prevalence of smoking in patients of lung tuberculosis in DOTS Polyclinic Prof. Dr R. D. Kandou Hospital, Manado. This was a descriptive cross - sectional study conducted in October 2014. Samples included 57 people. Total of lung tuberculosis patients who smoked were 33 people; 28 were males (84.8\%). In the age group of 56-65 years there were 9 people $(27.3 \%)$. The most frequent of jobs were self-employed (8 people; 24.2 $\%)$. The results showed that the incidence of smoking in patients of lung tuberculosis approximately $57.9 \%$.
\end{abstract}

Keywords: lung tuberculosis, smoking.

\begin{abstract}
Abstrak: Penyakit TB paru merupakan penyakit infeksi yang masih menjadi masalah kesehatan dalam masyarakat. Beberapa penelitian menyebutkan adanya hubungan yang signifikan antara merokok dengan TB paru. Penelitian ini bertujuan untuk mengetahui angka kejadian merokok pada pasien TB paru di Poliklinik DOTS RSUP Prof. Dr. R. D. Kandou Manado. Desain penelitian adalah cross-sectional terhadap pasien TB paru yang berobat di Poliklinik DOTS RSUP Prof. Dr. R. D. Kandou Manado pada bulan November 2014. Sampel berjumlah 57 orang. Jumlah pasien TB paru yang merokok adalah 33 orang, dimana jenis kelamin terbanyak laki-laki yaitu 28 orang $(84,8 \%)$. Kelompok umur 56-65 tahun adalah yang terbanyak yaitu 9 orang $(27,3 \%)$, dan pekerjaan terbanyak adalah wiraswasta 8 orang $(24,2 \%)$. Hasil dari penelitian ini didapatkan angka kejadian merokok pada pasien TB paru sekitar 57,9\% dari keseluruhan data.

Kata kunci: TB paru, merokok
\end{abstract}

Penyakit tuberkulosis paru merupakan penyakit infeksi yang masih menjadi masalah kesehatan dalam masyarakat kita. Penyakit ini berasal dari infeksi bakteri berbentuk batang (basil) Mycobacterium tuberculosis, ${ }^{1}$ Global Tuberculosis Report tahun 2013 menyatakan bahwa prevalensi kasus TB di Indonesia diperkirakan 506 orang per 100.000 penduduk. Angka insiden diperkirakan 220 orang per 100.000 penduduk, dan angka mortalitas sekitar 48 orang per 100.000 penduduk. ${ }^{2}$ Lima provinsi dengan TB paru tertinggi adalah Jawa Barat, Papua, DKI Jakarta, Gorontalo, dan Papua Barat. Untuk provinsi Sulawesi Utara, didapatkan prevalensi TB paru sebanyak 0,3\% (Riskesdas 2013). ${ }^{3}$

Separuh dari kematian karena TB paru pada laki-laki disebabkan merokok dan 3,25 dari perokok berkembang menjadi penderita TB paru. Kematian pada penderita TB paru adalah 4 kali lebih besar 
Silo, Wongkar, Langi: Angka kejadian merokok...

pada kelompok merokok dibanding yang tidak merokok. Faktor yang mempengaruhi terjadinya penyakit TB paru, antara lain kondisi sosial ekonomi, umur, jenis kelamin, status gizi dan kebiasaan merokok $^{4}$

Beberapa penelitian menyebutkan adanya hubungan yang signifikan antara merokok dengan TB paru. Dwi Sarwani dan Sri Nurlaela membuktikan melalui penelitian yang telah mereka lakukan dengan hasil bahwa terdapat hubungan positif antara merokok dengan TB paru. ${ }^{4}$ Berdasarkan hasil penelitian diatas, maka peneliti merasa terdorong untuk mengetahui berapa banyak kasus TB paru yang disebabkan oleh merokok sehingga akan mencoba melakukan penelitian tentang “Angka Kejadian Merokok pada Pasien TB Paru yang Berobat di Poliklinik DOTS pada Bulan November 2014“.

\section{METODE PENELITIAN}

Metode penelitian yang digunakan dalam penelitian ini adalahcross-sectional, dimana pengambilan data dilakukan di Poliklinik DOTS RSUP Prof. Dr. R. D. Kandou Manado selama bulan November 2014. Sampel yang didapat berjumlah 57 orang, dimana sampel merupakan pasien TB paru yang sedang dalam masa pengobatan.

\section{HASIL PENELITIAN}

Populasi dan Sampel: Sampel yang dapat dijaring berjumlah 57 orang. Catatan register pasien di Poliklinik DOTS RSUP Prof. Dr. R. D. Kandou Manado selama bulan November 2014 adalah 117 orang.

Distribusi Pasien Berdasarkan Jenis Kelamin didapatkan jumlah pasien TB Paru di Poliklinik DOTS berdasarkan jenis kelamin, yang terdiri dari laki-laki sebanyak 32 orang $(56,1 \%)$ dan perempuan sebanyak 25 orang $(43,9 \%)$ (Tabel 1).

Distribusi Berdasarkan Status Merokok: didapatkan jumlah pasien dengan status perokok ada 2 orang (3,5\%), yang pernah merokok sebanyak 31 orang $(54,4 \%)$ dan yang bukan perokok sebanyak 24 orang (42,1\%) (Tabel 2).
Tabel. 1. Distribusi Pasien berdasarkan jenis kelamin

\begin{tabular}{ccc}
\hline Jenis Kelamin & $\mathrm{N}$ & $\%$ \\
\hline Laki-laki & 32 & 56,1 \\
Perempuan & 25 & 43,9 \\
\hline Total & 57 & 100 \\
\hline
\end{tabular}

Tabel 2. Distribusi pasien berdasarkan riwayat merokok

\begin{tabular}{ccc}
\hline Riwayat merokok & $\mathrm{N}$ & $\%$ \\
\hline Perokok & 2 & 3,5 \\
Pernah merokok & 31 & 54,4 \\
Bukan perokok & 24 & 42,1 \\
\hline Jumlah & 57 & 100 \\
\hline
\end{tabular}

Tabel 3. Distribusi TB paru merokok berdasarkan jenis kelamin

\begin{tabular}{ccccc}
\hline Jenis kelamin & Perokok & $\%$ & $\begin{array}{c}\text { Bukan } \\
\text { perokok }\end{array}$ & $\%$ \\
\hline Laki - laki & 28 & 84,8 & 4 & 16,7 \\
Perempuan & 5 & 15,2 & 20 & 83,3 \\
\hline Jumlah & 33 & 100 & 24 & 100 \\
\hline
\end{tabular}

Distribusi TB paru merokok berdasarkan kelompok umur: didapatkan kelompok umur 17-25 tahun sebanyak 6 orang (18,2\%), umur 26-35 tahun sebanyak 7 orang (21,2\%), umur 36-45 tahun sebanyak 5 orang (15,2\%), umur 46-55 tahun sebanyak 2 orang $(6,1 \%)$, umur 56 65 tahun sebanyak 9 orang (27,3\%), dan umur $\geq 66$ tahun sebanyak 4 orang $(12,1 \%)$ (Tabel 4).

Distribusi TB paru merokok berdasarkan pekerjaan: didapatkan pekerjaan sebagai pegawai negeri sebanyak 2 orang (7\%), wiraswasta 8 orang (24,2\%), karyawan sebanyak 7 orang (21,2\%), pensiunan sebanyak 1 orang (3\%), petani sebanyak 1 orang (3\%), buruh sebanyak 5 orang (15,2\%), supir angkot sebanyak 2 orang $(6,1 \%)$, pelajar sebanyak 3 orang (9,1\%), IRT sebanyak 2 orang (6,1\%), dan yang tidak bekerja sebanyak 2 orang (6,1\%). Pekerjaan sebagai pendeta dan penjahit tidak didapatkan termasuk dalam 
kelompok pasien TB paru bukan perokok (Tabel 5).

Tabel 4. Distribusi TB paru merokok berdasarkan kelompok umur

\begin{tabular}{ccccc}
\hline $\begin{array}{c}\text { Kelompok } \\
\text { Umur }\end{array}$ & Perokok & $\%$ & $\begin{array}{c}\text { Bukan } \\
\text { perokok }\end{array}$ & $\%$ \\
\hline $\begin{array}{c}17-25 \\
\text { tahun }\end{array}$ & 6 & 18,2 & 4 & 16,7 \\
$26-35$ & 7 & 21,2 & 6 & 25,0 \\
tahun & & & & \\
$\begin{array}{c}36-45 \\
\text { tahun }\end{array}$ & 5 & 15,2 & 0 & 0 \\
$46-55$ & 2 & 6,1 & 6 & 25,0 \\
tahun & & & & \\
$56-65$ & 9 & 27,3 & 4 & 16,7 \\
tahun \\
$\geq 66$ & 4 & 12,1 & 4 & 16,7 \\
tahun & & & & \\
\hline Total & 33 & 100 & 24 & 100 \\
\hline
\end{tabular}

Tabel 5. Distribusi TB paru merokok berdasarkan pekerjaan

\begin{tabular}{ccccc}
\hline Pekerjaan & Perokok & $\%$ & $\begin{array}{c}\text { Bukan } \\
\text { perokok }\end{array}$ & $\%$ \\
\hline Peg. Negeri & 2 & 7,0 & 2 & 8,3 \\
Wiraswasta & 8 & 24,2 & 1 & 4,2 \\
Karyawan & 7 & 21,2 & 2 & 8,3 \\
Pensiunan & 1 & 3,0 & 3 & 12,5 \\
Petani & 1 & 3,0 & 1 & 4,2 \\
Buruh & 5 & 15,2 & 0 & 0 \\
Supir angkot & 2 & 6,1 & 0 & 0 \\
Pelajar & 3 & 9,1 & 1 & 4,2 \\
IRT & 2 & 6,1 & 8 & 33,3 \\
Pendeta & 0 & 0 & 1 & 4,2 \\
Penjahit & 0 & 0 & 2 & 8,3 \\
Tdk bekerja & 2 & 6,1 & 3 & 12,5 \\
\hline Total & 33 & 100 & 24 & 100 \\
\hline
\end{tabular}

\section{BAHASAN}

Berdasarkan data yang ada di Poliklinik DOTS RSUP Prof. Dr.R. D. Kandou Manado selama bulan November 2014, didapatkan jumlah penderita TB Paru sebanyak 117 orang, dan yang bersedia mengikuti penelitian sebanyak 57 orang.

Hasil distribusi Tabel 1 didapatkan bahwa jumlah pasien TB Paru lebih banyak menyerang pada laki-laki dibandingkan perempuan. Pasien TB Paru pada pria sebanyak 32 orang $(56,1 \%)$ dan pada wanita sebanyak 25 orang (43,9\%).

Pada hasil Tabel 2 memperlihatkan keseluruhan jumlah perokok dan pernah merokok sebanyak 33 pasien. Perhitungan insiden merokok pada studi ini menyertakan kelompok 1 dan 2 (perokok dan pernah merokok) dengan alasan bahwa pasien dengan status sebagai perokok adalah pasien yang pada saat wawancara dilakukan dan bahkan saat sudah terdiagnosis menderita penyakit TB paru mengaku masih merokok. Pasien yang mengaku pernah merokok adalah pasien yang saat wawancara dilakukan mengakui pernah merokok dan berhenti merokok pada saat sudah terdiagnosis TB paru, sehingga insiden merokok pada pasien dalam penelitian ini didapatkan 57,9\%. Hal ini menunjukkan kemungkinan besar rokok berpengaruh terhadap kejadian TB Paru. Dalam penelitian ini pasien yang tidak merokok sebanyak 24 orang (42,1\%), akan tetapi hal ini belum dapat menyingkirkan adanya risiko sebagai perokok pasif.

Hasil distribusi pada Tabel.3 menunjukkan pasien TB paru merokok lebih banyak berjenis kelamin laki-laki (84,8\%) dibanding perempuan (15,2\%). Hasil penemuan ini sesuai dengan hasil Riskesdas tahun 2013 yang menunjukkan bahwa di Indonesia prevalensi TB paru pada laki-laki lebih tinggi 10\% dibandingkan perempuan. ${ }^{3}$ Lebih tingginya angka penemuan kasus TB Paru pada lakilaki dibanding perempuan dapat dilihat dari segi pajanan pada risiko infeksi, termasuk gaya hidup seperti merokok, dan juga pekerjaan yang berasal dari polutan udara dari luar ruangan khusunya yang berhubungan dengan paparan industri. ${ }^{5}$

Berdasarkan hasil distribusi tabel.4 didapatkan kelompok umur pasien TB paru merokok yang paling rentan terkena penyakit ini pada usia mendekati pensiun yaitu 56-65 tahun sebanyak 9 orang (27,3\%). Namun pada pasien TB paru bukan perokok didapatkan kelompok umur paling rentan terjadinya penyakit ini pada usia 26-35 tahun dan 46-55 tahun yaitu sebanyak 6 orang (25\%). Hasil yang didapat berbeda dengan keputusan Kementrian Kesehatan RI dalam Pedoman Nasional Pengendalian Tuberkulosis tahun 
2011 yang menyatakan bahwa sekitar 75\% pasien TB Paru adalah kelompok usia produktif. Pada kelompok umur 56-65 tahun yang merupakan usia pensiunan, kemungkinan lebih memilih pengobatan di rumah sakit dibanding puskesmas. Data yang diambil hanya observasi langsung di Poliklinik DOTS Rumah Sakit dalam jangka waktu satu bulan sehingga data yang didapat tidak bisa mencerminkan prevalensi menurut kelompok umur yang sebenarnya.

Dari hasil distribusi pada Tabel 5 didapatkan pekerjaan pasien TB paru merokok paling banyak bekerja sebagai wiraswasta sebanyak 8 orang (24,2\%), sedangkan pada pasien TB paru bukan perokok paling banyak bekerja sebagai IRT berjumlah 8 orang (33,3\%). Hasil yang didapatkan pada penelitian ini sama dengan yang dikemukakan oleh Wuaten ${ }^{6}$ di Manado yang mendapatkan hasil berdasarkan jenis pekerjaan terbanyak ialah sebagai wiraswasta (20\%).

\section{SIMPULAN}

Hasil penelitian terhadap angka kejadian merokok pada pasien TB Paru yang berobat di Poliklinik DOTS RSUP. Prof. Dr. R. D. Kandou Manado selama bulan November 2014, berdasarkan persentase sebagai berikut:

1. Angka kejadian merokok pada pasien TB paru sebanyak 57,9 \%
2. Pasien TB paru merokok terbanyak berjenis kelamin laki-laki 28 orang $(84,8 \%)$ dan perempuan 5 orang $(15,2 \%)$.

3. Distribusi pasien TB paru merokok berdasarkan kelompok umur pada rentan umur 56-65 tahun (27,3\%).

4. Distribusi pasien TB merokok berdasarkan pekerjaan terbanyak yaitu sebagai wiraswasta $(24,2 \%)$.

\section{DAFTAR PUSTAKA}

1. Naga SS. Buku panduan lengkap ilmu penyakit dalam. Jogjakarta: Diva Press.

2. Global Tuberculosis Report. Chapter 1 Introduction; 2013. p.9-10.

3. Badan Penelitian dan Pengembangan Kesehatan Depkes RI. Riset Kesehatan Dasar tahun 2013. Jakarta: Balitbangkes Depkes RI; 2013.

4. Sarwani D, Nurlaela S. Merokok dan tuberkulosis paru : Studi kasus di RS Margono Soekarjo Purwokerto. Prosiding Seminar Nasional Kesehatan; 2012 Maret 31; UNSOED. Purwokerto: Jurusan Kesehatan Masyarakat FKIK UNSOED;c2012.

5. Allotey $\mathbf{P}$, Gyapong $\mathbf{M}$. Gender in tuberculosis research. Int J Tuberculosis Lung Disease. 2008;12:831-6.

6. Wuaten GA. Hubungan antara kebiasaan merokok dengan penderita TB paru. Manado: Universitas Sam Ratulangi; 2012. 